\title{
Investigation for additional head loss in helically coiled flexible pipe of a mobile fertigation system
}

\author{
Aliaksandr Basareuski ${ }^{1 *}$ \\ ${ }^{1}$ Republican Unitary Enterprise «Scientific and practical centre of the National Academy of sciences of Belarus of agriculture \\ mechanization», Belarus
}

\begin{abstract}
One of the major parameters of a hydraulic machine is its energy intensity, i.e. its power/output ratio. This article presents the results of theoretical studies of the effects of additional head loss of transporting fluid through helically coiled flexible pipe on specific energy consumption of fertigation machinery and pipeline transport. Computational methods have been used to determine that pressure loss will be $15-20 \%$ higher on the average than the loss at a straight section, depending on the average radius of coil helix/design pipe diameter ratio. Correlations have been obtained that allow for justification of major mobile fertilizer system parameters based on the need to minimize pressure loss.
\end{abstract}

\section{Problem Statement}

In agricultural production, machinery with flexible coiled pipes is finding ever-widening applications. Thus, mobile hose-reel irrigation machines (HRIM) are used worldwide. Flexible pipes coiled on reels allow for using advanced fertigation patterns, increase the distance between closed irrigation system pipelines and irrigation valves, completely automate the irrigation process, and reduce its labor intensity and energy intensity. In animal husbandry, such transport systems are used in milking plants, for fodder preparation and distribution, and for manure water wash. Pipeline transport is efficient; it combines loading and unloading operations with transportation and provides high sanitary benefits. At the same time, the major limitation of such systems is the increased pressure loss in the water supply system. To reduce energy consumption per production unit, the water supply system must deliver fluid with the lowest pressure loss. As required methods for flexible pipe dimensioning are missing, pressure loss reduction in fluid transport and, thus, energy intensity reduction in the described systems still remain a challenging issue.

\subsection{Past Studies and Publications}

Investigations of researchers in Germany, Switzerland, Italy, France, England, USA, etc. established that plastic pipes are hydraulically smooth [1]. Therefore, a number of authors have obtained semi-empirical equations for the Darcy factor, which do not take roughness into account.

It should be noted that there have been some studies of hydraulic resistance in pipes helically coiled on a reel
$[2,3,4-7]$. However, up to the present time, this issue has been little studied and is therefore very relevant.

It should be noted that the fluid behavior in a helically coiled pipe is somewhat different from that in a straight pipe. Thus, the transition to turbulence occurs at higher $R e$ values than in a straight pipe $[2,3]$. In the above articles, the common ground is that all the authors determine the friction factor based on the ratio of the coil diameter to the flexible pipe outside diameter $\left(D_{\mathrm{c}} / d_{\mathrm{o}}\right)$. However, the correlations obtained in articles [2, 3, 4] only cover the area up to $\operatorname{Re} \leq 10^{5}$ and are therefore not applicable to dimensioning of flexible pipe systems (machinery) with high-turbulence fluid flow.

Particular attention should be given to article [7] that states that head loss in flexible pipe coiled on a reel is $10 . .20 \%$ higher than at a straight section, depending on the radius of coil helix. The limitation of this article is that the experiments only cover small-diameter pipes, and extrapolation to larger diameters is hardly acceptable.

The aim of our research is to evaluate the effects of additional resistance in helically coiled flexible pipe on energy intensity of mobile fertigation equipment and pipeline transport.

\section{Research Results}

One of the major parameters of a hydraulic machine is its energy intensity, i.e. its power/output ratio. For pipeline transport, energy consumption will be in proportion to flow and head. Therefore, energy intensity is determined by head. The higher head loss (hydraulic resistance) is, the higher energy consumption is for pumping fluid through a water supply system.

For machinery with helically coiled flexible pipes, energy intensity, in addition, will depend on certain 
design limitations. According to the recommendations in [8], the inside coil diameter must be at least 20 times larger than the flexible pipe outside diameter. This limitation is mainly due to creation of high pipe ovality (over 3\%) when coiling flexible pipe on a reel. However, as experiments have shown, if HDPE 63 or higher grade is used, in order to reduce material consumption, this ratio can be decreased to 13.6 without increasing ovality [9]. A further decrease in $D_{\mathrm{c}} / d_{\mathrm{o}}<13.6$ will lead to a significantly increased ovality. Therefore,

$$
\frac{D_{\mathrm{c}}}{d_{\mathrm{o}}}=13.6 \div 20
$$

where $D_{\mathrm{c}}$ is the flexible pipe coil diameter $[\mathrm{m}]$; $d_{\mathrm{o}}$ is the flexible pipe outer diameter $[\mathrm{m}]$.
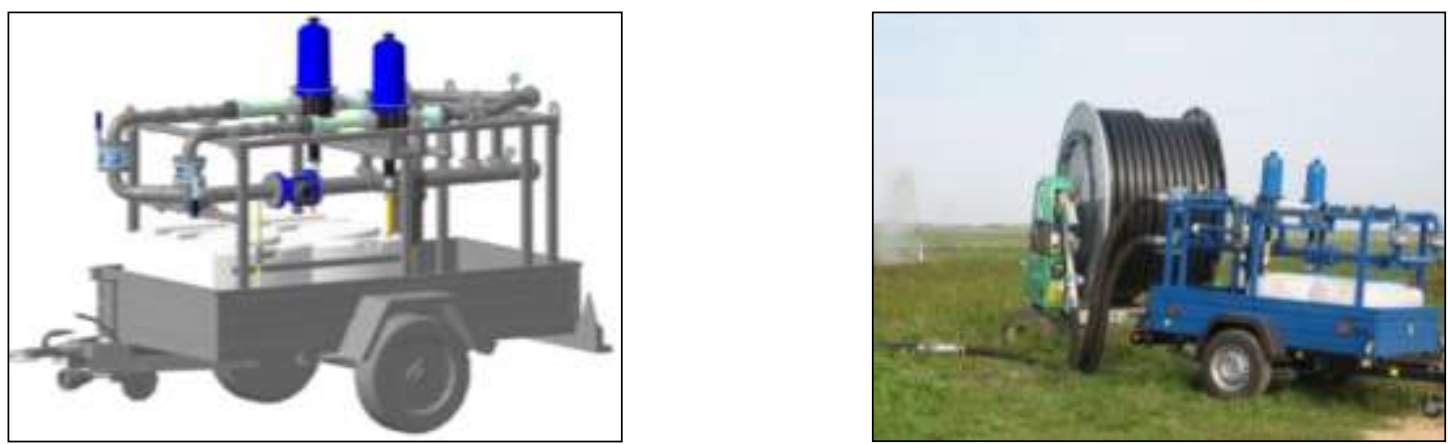

a)

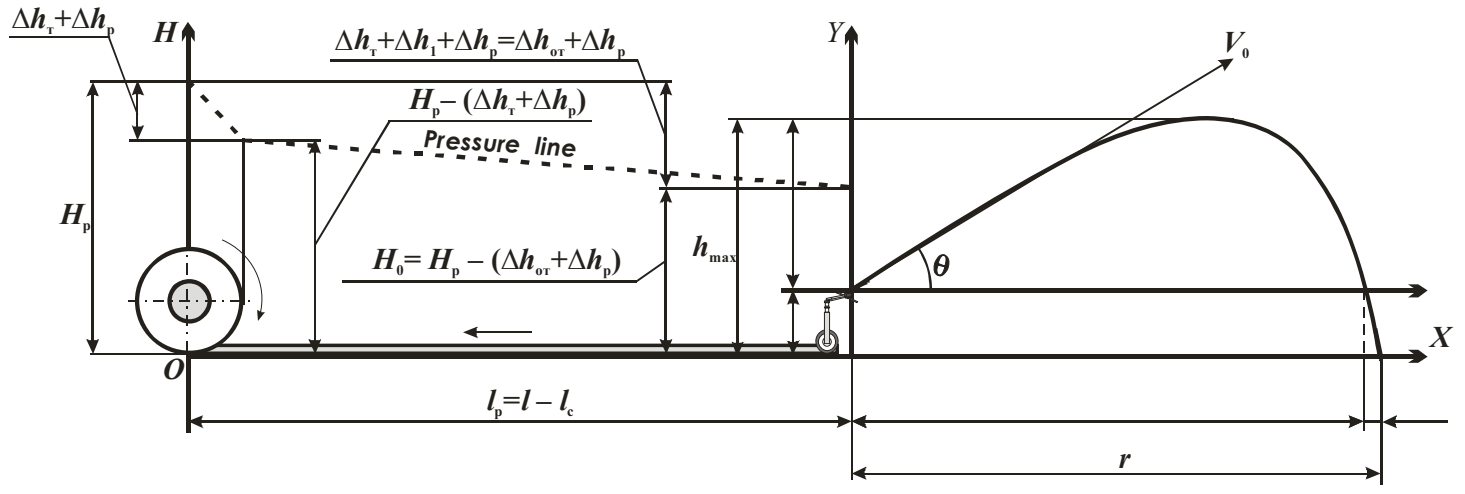

b)

Fig. 1. Mobile fertilizer system: a) 3D model of the equipment and general view of the system; $b$ ) chart for determining hydraulic parameters; $H_{\mathrm{p}}$ - working head [m]; $H_{0}$ - sprinkler head pressure $[\mathrm{m}] ; \Delta h_{\mathrm{p}}-$ head loss in drive $[\mathrm{m}] ; h_{\max }-$ maximum altitude of jet flight $[\mathrm{m}] ; r-$ jet range[m]; $\theta$ - tilt angle of sprinkler $[\mathrm{rad}] ; V_{0}-$ initial jet speed $[\mathrm{m} / \mathrm{s}]$.

The radius of coil helix for the $i$-th flexible pipe layer can be determined using the following equation:

$$
R_{c i}=R_{r}+\frac{k_{1} d_{\mathrm{o}}}{2}+(i-1) k_{1} d_{\mathrm{o}},
$$

where $R_{r}$ is the reel radius [m];

$k_{1}$ is the flexible pipe radial ovality factor equal to 0.99 [8].
The ratio (1) expresses the design limitation of the parameters of coiling flexible pipe onto a reel.

We will explore hydraulic parameters of helically coiled flexible pipe on the example of HRIMs. Depending on capacity, their energy intensity ranges from 55 to $64 \mathrm{kWh} / \mathrm{ha}$ [10]. Fig. 1 shows a 3D model and a general view of OGD-50 fertilizer injector prototype (a) operated together with a mobile HRIM and the hydraulic parameter dynamics chart (b) during the irrigation cycle of this fertilizer system. 
Taking into account equation (3), the Weisbach equation for a smooth pipe curve [11] for coiled pipeline with $n$ coils and $m$ layers will be as follows:

$$
\xi_{\text {bend }}=4 n\left(0.131+1.844\left(\frac{d_{\mathrm{d}}}{2 R_{r}+k_{1} d_{\mathrm{o}} m}\right)^{3,5}\right) \text {. }
$$

where $\xi_{\text {bend }}$ is the local hydraulic resistance factor; $d_{\mathrm{d}}$ is the flexible pipe design diameter [m]; $\delta$ is the flexible pipe curvature [rad].

Aronov's article [6] is especially noteworthy; the author established that in the high turbulence area, the curves $\lambda=f(R e)$ for curved and straight pipes run in parallel, and the total hydraulic resistance factor in curved pipes is a sum of factors taking into account the main flow friction and transverse circulation. The resistance factor ratio in curved and straight pipes is as follows:

$$
C=\frac{\lambda_{\text {curv }}}{\lambda_{\text {str }}}=\frac{\lambda_{\text {str }}+\lambda_{\text {bend }}}{\lambda_{\text {str }}}>1
$$

where $\lambda_{\text {curv }}$ is the total hydraulic resistance factor in a curved pipe;

$\lambda_{\text {str }}$ is the hydraulic resistance factor in a straight pipe;

$\lambda_{\text {bend }}$ is the hydraulic resistance factor corresponding to an additional loss.

Based on his studies and depending on the ratio of the average radius of coil helix to the flexible pipe design diameter $\left(R_{\mathrm{c}} / d_{\mathrm{d}}\right)$, Aronov recommends the values of $\mathrm{C}$ [6] that we have approximated using the following correlation:

$$
C=\frac{1.816}{\left(\frac{R_{\mathrm{c}}}{d_{d}}\right)^{0.156}}
$$

Then head loss in helically coiled flexible pipe calculated using the Darcy-Weisbach equation and taking into account condition (5) and Konakov equation [12] is as follows:

$$
\Delta h_{\mathrm{r}}=\frac{0.081 l_{\mathrm{c}} Q^{2} C}{d_{d}^{5} g\left(9.489+0.782 \ln \frac{Q}{d_{d}}\right)^{2}},
$$

where $l_{\mathrm{c}}$ the length of flexible pipe coiled on the reel [m]; $Q$ is the flow rate (throughput) $\left[\mathrm{m}^{3} / \mathrm{s}\right]$; $g$ is the gravity acceleration $\left[\mathrm{m} / \mathrm{s}^{2}\right]$,

and taking into account equations (3) and (5) we obtain the following:

$$
\Delta h_{\mathrm{r}}=\frac{1.472 l_{\mathrm{c}} Q^{2}}{d_{d}^{5} g\left(9.489+0.782 \ln \frac{Q}{d_{d}}\right)^{2} \cdot\left(\frac{R_{\mathrm{r}}+\frac{1}{2} k_{1} d_{\mathrm{o}} m}{d_{d}}\right)^{0,156}} .
$$

The table shows pressure loss calculated using equations (4) and (8) in helically coiled pipe.

Table 1. Analysis of equations for hydraulic dimensioning of helically coiled pipe

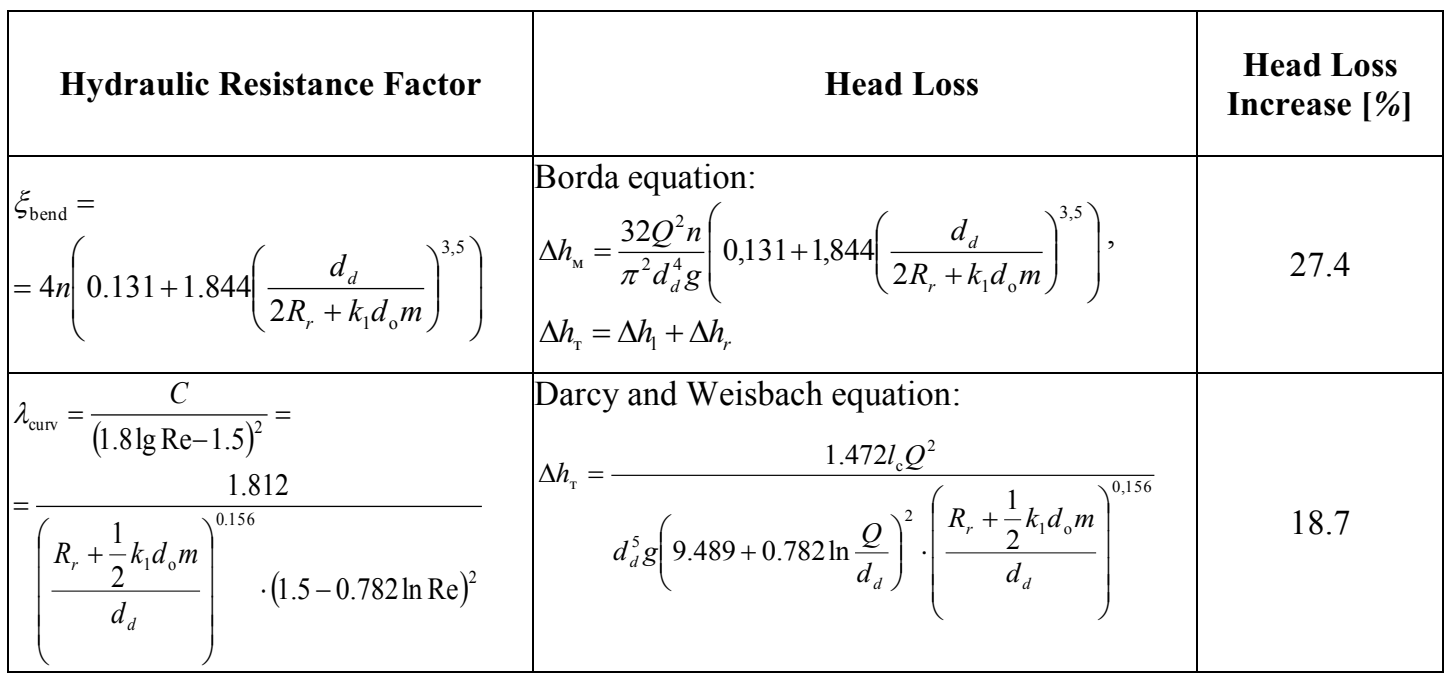

Notes.

1. Calculations were made for $d_{d}=60.65 \cdot 10^{-3}$ and pipeline length $l_{\mathrm{c}}=100 \mathrm{~m}$ at $Q=10.91 \cdot 10^{-3} \mathrm{~m}^{3} / \mathrm{s} ; R_{\mathrm{c}}=0.75 \mathrm{~m} ; n=13 ; m=4.7$.

2. At water temperature $15^{\circ} \mathrm{C}, v=1 \cdot 10^{-6} \mathrm{~m}^{2} / \mathrm{s}$ (taken into account in numerical factors).

It can be seen from the table that the increase in head loss in helically coiled pipe, as compared with a straight section, is $27.4 \%$ when calculated according to the first equation and $18.7 \%$ when calculated according to the second equation. In the second case, the result is close to the experimental data, according to which loss increases by $10 \ldots 20 \%$ depending on the $R_{\mathrm{c}} / d_{d}$ ratio [13]. In the first case, the equation gives a large error and is only suitable for estimations. 
Fig. 2 shows, based on (8) and Konakov equation [12], a chart is given for $\Delta h_{\mathrm{T}}=f(Q)$ correlation per $100 \mathrm{~m}$ of pipeline and $d_{d}=60.65 \cdot 10^{-3} \mathrm{~m}$ for straight pipe and helically coiled pipe at different $R_{\mathrm{c}} / d_{\mathrm{d}}$ ratios.

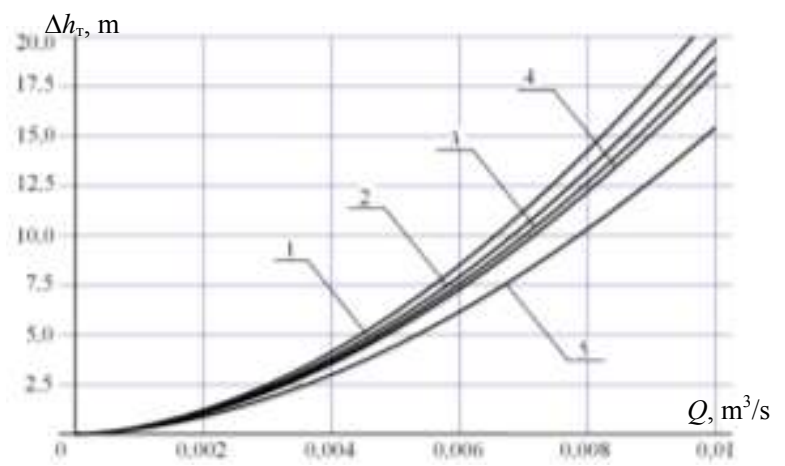

Fig. 2. Chart for head loss/flow correlation: $1-\frac{R_{\mathrm{c}}}{d_{d}}=5.77 ; 2-$

$\frac{R_{\mathrm{c}}}{d_{d}}=9.07 ; 3-\frac{R_{\mathrm{c}}}{d_{d}}=12.37 ; 4-\frac{R_{\mathrm{c}}}{d_{d}}=15.66 ;$

5- straight pipeline.

It is clear from the chart that as the ratio $R_{\mathrm{c}} / d_{d}$ increases, loss $\Delta h_{\mathrm{T}}$ will decrease and approach loss $\Delta h_{1}$. Thus, at $Q=0.008 \mathrm{~m}^{3} / \mathrm{s}$, loss at a straight pipeline section will be $\Delta h_{\mathrm{T}}=10.3 \mathrm{~m}$, while in coiled pipeline with $R_{\mathrm{c}} / d_{\mathrm{d}}=5.77$, loss will be $\Delta h_{\mathrm{T}}=14.2 \mathrm{~m}$, and with $R_{\mathrm{c}} / d_{\mathrm{d}}=15.66$, loss will be $\Delta h_{\mathrm{T}}=12.2 \mathrm{~m}$, which is 37.9 and $18.4 \%$ higher than at a straight section, respectively.

However, the resulting chart (Fig. 2) demonstrates pressure loss with fully coiled flexible pipe (at the end of the irrigation cycle). Actual total pressure loss will consist of the coiled pipe loss and the straight section loss:

$$
\Delta h_{\text {обт }}=\Delta h_{\mathrm{T}}+\Delta h_{1} .
$$

where $\Delta h_{1}$ is head loss along flexible pipe length [m].

After placing equation (8) and Konakov equation [12] in (9) and necessary transformations, we obtain the following:

$$
\Delta h_{\mathrm{oT}}=\frac{Q^{2}\left(1.472 l_{\mathrm{c}}+0.727 l_{d}\left(\frac{2 R_{r}+k_{1} d_{\mathrm{o}} m}{d_{d}}\right)^{0.156}\right)}{d_{d}^{5} g\left(9.489+0.782 \ln \frac{Q}{d_{d}}\right)^{2} \cdot\left(\frac{R_{\mathrm{r}}+\frac{1}{2} k_{1} d_{\mathrm{o}} m}{d_{d}}\right)^{0.156} .}
$$

Fig. 3 shows a chart of the correlation obtained for coiling onto a reel at $Q=10.91 \cdot 10^{-3} \mathrm{~m}^{3} / \mathrm{s}, R_{\mathrm{r}}=0.75 \mathrm{~m}$ and $l=370 \mathrm{~m}$.

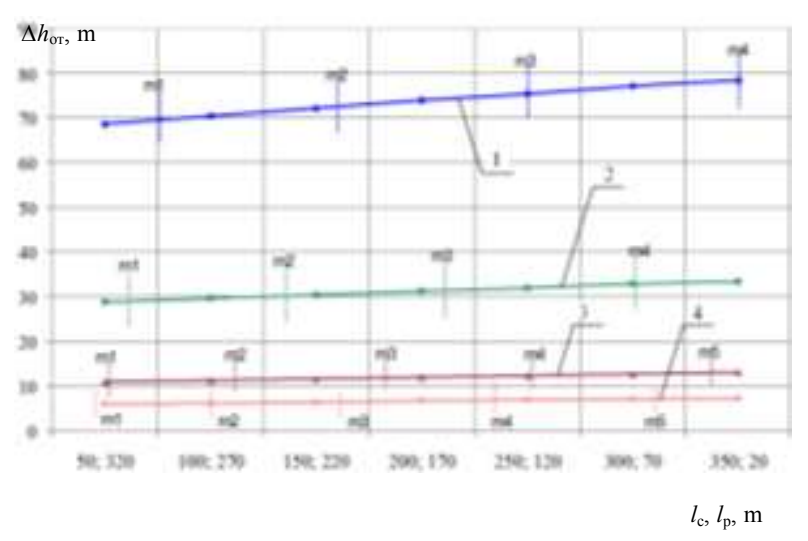

Fig. 3. Chart for the correlation of head loss/pipe length during its coiling onto the reel: $1-d_{\mathrm{o}}=0.075 \mathrm{~m} ; 2-d_{\mathrm{o}}=0.090 \mathrm{~m} ; 3-$ $d_{\mathrm{o}}=0.110 \mathrm{~m} ; 4-d_{\mathrm{o}}=0.125 \mathrm{~m} ; \mathrm{m} 1, \mathrm{~m} 2 \ldots \mathrm{mn}-$ number of flexible pipe layers.

Thus, for a pipeline with $d_{\mathrm{o}}=0.075 \mathrm{~m}$, the loss difference in the coiled and uncoiled condition is $11.7 \mathrm{~m}$, while for $d_{\mathrm{o}}=0.090 \mathrm{~m}$, this difference will be $5.6 \mathrm{~m}$ and for $d_{\mathrm{o}}=0.110 \mathrm{~m}$ and $d_{\mathrm{o}}=0.125 \mathrm{~m}$, the differences are $2.4 \mathrm{~m}$ and $1.4 \mathrm{~m}$, respectively. To reduce loss, $R_{r}$ must be increased in accordance with (1). This is mostly feasible for pipelines with $d_{\mathrm{o}}=0.110 \mathrm{~m}$ or higher, as with smaller $d_{0}$, specific material consumption will increase with the increase of $R_{\mathrm{r}}$. It can also be seen from the figure that with identical structural parameters, the number of layers $m$ increases with the increase of $d_{0}$.

Further, we will see how head loss varies depending on the inside reel diameter $R_{r}$ at similar parameters (Fig. 4).

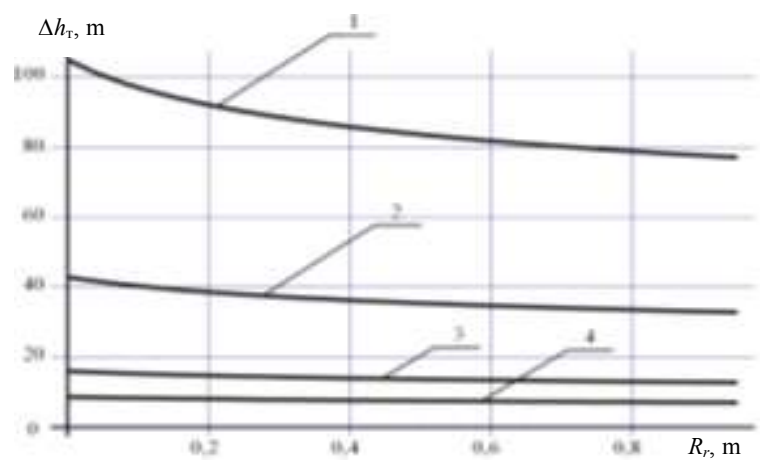

Fig. 4. Chart for head loss/inside reel diameter correlation in flexible pipe: $1-d_{0}=0.075 \mathrm{~m}$ and $m=4.1 ; 2-d_{0}=0.09 \mathrm{~m}$ and $m=4.7 ; 3-d_{\mathrm{o}}=0.110 \mathrm{~m}$ and $m=5.3 ; 4-d_{\mathrm{o}}=0.125 \mathrm{~m}$ and $m=5.6$.

As we see, head loss increases as the inside reel diameter $R_{r}$ and flexible pipe diameter $d_{\mathrm{o}}$ decrease. Thus, with $d_{\mathrm{o}}=0.075 \mathrm{~m}$ and $R_{r}=0.6 \mathrm{~m}$, head loss is $\Delta h_{\mathrm{T}}$ $=81.8 \mathrm{~m}$. At the same time, with $R_{r}=0.85 \mathrm{~m}(41.7 \%$ increase), head loss is $\Delta h_{\mathrm{T}}=78.2 \mathrm{~m}$. Thus, with the same flexible pipe length, head loss decreased by $3.6 \mathrm{~m}$ $(4.4 \%)$. Similarly, for the indicated parameters with $d_{\mathrm{o}}=0.09 \mathrm{~m}$, head loss reduction is $1.4 \mathrm{~m}(4 \%)$ and, accordingly, with $d_{\mathrm{o}}=0.110 \mathrm{~m}$ and $d_{\mathrm{o}}=0.125 \mathrm{~m}$, head loss reduction is $0.5 \mathrm{~m}(3.8 \%)$ and $0.3 \mathrm{~m}(3.7 \%)$.

Thus, the above energy consumption of HRIM can be reduced to an average of $45-50 \mathrm{kWh} / \mathrm{ha}$ by justifying 
efficient design and operating system parameters based on the need to minimize pressure loss.

\section{Conclusion}

To justify the design parameters and operating modes of machines and systems with helically coiled flexible pipes, it is necessary to accurately determine pressure loss in the water supply system.

It is established that the ratio of the coil diameter to the flexible pipe outer diameter must be within the range of $D_{\mathrm{c}} / d_{\mathrm{o}}=13.6-20$. Computational methods have been used to determine that pressure loss, depending on the average radius of coil helix/ pipe diameter ratio $R_{\mathrm{c}} / d_{\mathrm{o}}$, will be $15-20 \%$ higher on the average than the loss at a straight section (equation 10).

The analysis of equation (10) showed that, in order to reduce head loss (energy consumption), it is necessary to increase $R_{r}$ and $d_{\mathrm{o}}$ in the above range of $D_{\mathrm{c}} / d_{\mathrm{o}}$ ratio (equation 1). This is mostly feasible for pipelines with $d_{\mathrm{o}}$ $=0.110 \mathrm{~m}$ or higher, as with smaller $d_{0}$, specific material consumption will increase with the increase of $R_{r}$. With identical structural parameters, the number of layers $m$ increases with the increase of $d_{\mathrm{o}}$. Due to the reduced pressure loss, energy consumption for transporting fluid through the water supply system of the fertilizer equipment and the irrigation system can be reduced by $15-18 \%$.

The correlations obtained will allow accurately determine and minimize pressure loss. This will help to reduce energy consumption with the same capacity and determine required design parameters for fertigation systems.

\section{References}

1. M.Ya. Ruzin. Gidravlicheskiy raschet plastmassovykh truboprovodov. Vodosnabzh. i sanit. tekhnika № 9, 1-5 (1962)

2. V.G Fastovskiy, A.E. Rovinskiy Issledovanie teplootdachi $\mathrm{v}$ spiral'nom kanale. Teploenergetika, № 1, 39-41(1957)

3. Yu.V. Kvitkovskiy. Gidravlicheskoe soprotivlenie plavno izognutykh trub. Sb. nauch. tr. Moskovskiy in-t inzh. zheleznod. transp. M., Vyp. 176, 61-63 (1963)

4. I.E. Idel'chik. Spravochnik po gidravlicheskim soprotivleniyam. M.: Mashinostroenie (1975)

5. I.Z. Aronov. O dvizhenii zhidkosti v izognutykh trubakh-zmeevikakh. Izvest. vyssh. uchebn. zavedeniy. Energetika, № 3, 65-74 (1961)

6. I.Z. Aronov. O gidrodinamicheskom podobii pri dvizhenii zhidkosti $\mathrm{v}$ izognutykh trubakhzmeevikakh. Izvest. vyssh. uchebn. zavedeniy. Energetika, № 4, 130-132 (1962)

7. S.S. Savushkin, S.B. Khrol', T.M. Nekrasova. K voprosu o dopolnitel'nom soprotivlenii, voznikayushchem pri dvizhenii zhidkosti v polietilenovom shlange, navitom na baraban. Sb. nauch. tr. VNIIGiM, 134-140 (1983)
8. Truby napornye iz polietilena. Tekhnicheskie usloviya: GOST 18599-2001. Minsk: Mezhgos. sovet po standartizatsii, metrologii i sertifikatsii: Belorus. gos. in-t standartizatsii i sertifikatsii (2003)

9. E.Ts. Peterson. Ekspluatatsionnye svoystva orositel'nykh napornykh truboprovodov iz polietilena. Elgava (1987)

10. V.N. Dashkov, A.N. Basareuski. Sovremennaya energosberegayushchaya tekhnika dlya poverkhnostnogo poliva. Energoobespechenie i energosberezhenie $\mathrm{v}$ sel'skom khozyaystve. M.: VIESKh, Ch. 2, 168-173 (2008)

11. B.O. Botuk. Gidravlika. M.: Vysshaya shkola (1962)

12.F.A. Shevelev. Issledovanie osnovnykh gidravlicheskikh zakonomernostey turbulentnogo dvizheniya $\mathrm{v}$ trubakh. M.: VODGEO (1953)

13. V.N. Dashkov, N.F. Kapustin, A.N. Basareuski. Opredelenie gidravlicheskikh poter' $\mathrm{V}$ gibkom truboprovode barabanno-shlangovoy dozhdeval'noy ustanovki. Energosberegayushchie tekhnologii i tekhnicheskie sredstva $\mathrm{V}$ sel'skokhozyaystvennom proizvodstve. Minsk: BGATU, Ch. 1. - S. 72-78 (2008) 